\title{
Laboratory Investigation of The Contributions of Rubber Latex to Tensile Strength of Hot Mix Asphalt Concrete Using Split Cylinder and Double Punch Tests
}

\author{
Enwuso A. Igwe, Emmanuel O. Ekwulo \& Captain G. Ottos \\ Department of Civil Engineering, Rivers State University of Science and Technology, Nkpolu Oroworukwo \\ P.M.B 5080, 5080, Port Harcourt, Rivers State, Nigeria
}

\begin{abstract}
Flexible pavement design methods based on elastic theories require as input the elastic properties of the pavement materials. In particular the tensile properties of the pavement are of great concern in order to have sustainable and durable pavement during its useful life over the design period. However, determining the tensile properties of flexible pavement is one that has gained interest over the years. The present study used two forms of indirect tensile testing techniques (split cylinder and double punch) to determine tensile behaviour of asphalt concrete mixes synonymous with flexible pavement under loading for a rubber latex modified concrete. The results revealed that tensile strength of the asphalt concretes from the split cylinder test increased with increasing rubber latex content to a threshold value of $1.5 \%$ rubber latex content which was same for results from double punch test. However, the addition of rubber latex at this threshold value produced a $113 \%$ increase in the tensile strength of the asphalt concretes from split cylinder test and $133 \%$ increase in the tensile strength of the asphalt concretes from double punch test. Lastly, the results revealed that tensile strength from split cylinder test generally produced higher stress resistance than tensile strength from double punch test.
\end{abstract}

Keywords: Tensile Strength, HMA Concrete, Rubber Latex, Split Cylinder and Double Punch.

\section{Introduction}

The most important hot-mix asphalt (HMA) property influencing the structural response of a flexible pavement is the HMA stiffness modulus ( $\mathrm{E}_{\mathrm{HMA}}$ ) (Garcia and Thompson, 2007). Thus, flexible pavement design methods based on elastic theories require that the elastic properties of the pavement materials be known; Brown and Foo (1989).

In highway engineering design of flexible pavements, material characterization is such an important aspect that precedes the actual design of the pavement. The term characterization of pavement materials refers to the evaluation of the properties of the individual materials that make up the pavement. Also, it includes evaluating the properties of the pavement as a conglomerate such that its performance during use is sufficient to sustain the various loading conditions (traffic, thermal, moisture, wind etc) during the design period without deterioration, deformation or failure. The importance of pavement characterization of the material make-up is that it helps the engineer to know whether or not a material will be suitable to achieve desired results in terms of performance during the design period. A proper knowledge of material characterization helps to compensate for fatigue cracking in the asphalt bound layer of flexible pavements.

It is common knowledge amongst highway engineers that flexible pavements are easily simulated in the laboratory using asphaltic or bituminous mixtures. Therefore, the performance of bituminous mixtures in the laboratory can be used to predict the behaviour of flexible pavements under similar conditions. However, in reality the prediction of the performance of flexible pavement under service condition is one that is challenging to highway engineers due mainly to non-homogeneity of the material make up of the pavement, irregular vehicular loading and varying environmental conditions such as temperature, moisture and oxidation rates (Igwe et al., 2009). All of these challenges further buttress the importance of material characterization.

There are various types of tests that are used for material characterization. Examples include - simple flexural beam fatigue test in third point loading of rectangular specimens (Epps and Monismith 1969), cantilever-type loading of trapezoidal specimens (Bonnot 1986) and diametral loading in indirect tensile mode (Said, 1998). According to Mallick and El-Korchi 2013: p280, the Indirect Tensile test by splitting cylindrical specimens is one of the three most important tests used in material characterization of hot mix asphalt concretes (HMA) which simulate flexible pavements. The other two according to their work are resilient modulus and dynamic modulus. The importance of indirect tensile strength test is that it is used to measure the tensile properties of asphalt or bituminous mixtures such that the results can be used for fatigue analysis of pavements (Anderson et al., 2001 and Huang et al., 2008). Their separate studies reveal that the resistance of bituminous mixtures to fatigue cracking is dependent upon its tensile properties, notably its tensile strength and extensibility 
characteristics. On the other hand double punch test first develop by (Chen, 1970) to determine the tensile strength of concrete later became an important test for asphalt mixtures too (Chen, 1975).

The importance of tensile strength properties of asphalt concrete is that it is indicative of the fatigue behavior of asphalt concrete pavement (Igwe, 2015). Fatigue failure, generally defined as a failure resulting from the repetitive action of loads from traffic moving over the pavement (Romanoschi et al, 2006). Typically, failure becomes visible, only after a long number of load repetitions, and results initially in the formation of small cracks. These small cracks are initially located in the wheel path and appear as a network of fine cracks. Fatigue failure of the pavement is often believed to start when a fatigue crack initiates at the bottom of the bituminous layers of the pavement, due to local tensile strains, and propagates through the complete thickness of the pavement becoming apparent on the top surface (Robins, 2009).

The layers in a flexible pavement structure are subjected to continuous flexing as a result of the traffic loads that they carry, resulting in tensile stresses and strains at the bottom of the bituminous layers of the pavement. The magnitude of the strain is dependent on the overall stiffness of the pavement.

1.1 Objective: The objective of the research study was to investigate the effects by way of contribution that rubber latex (natural rubber) will have on the tensile strength (using split cylinder and double punch tests) of hot mix asphalt/bituminous concrete mixtures which are used to represent actual behavior of flexible pavements in reality. The research considered was for a light traffic category represented in the laboratory by compacting specimen at 35 blows on both faces.

1.2 Research Significance: The values of indirect tensile strength from split cylinder test and double punch strength may be used to evaluate the relative quality of bituminous mixtures in conjunction with laboratory mix design, testing and for estimating the resistance to cracking. The results can also be used to determine the resistance to field pavement moisture when results are obtained on both water conditioned and unconditioned specimens (Malhotra, 1967; Kennedy and Hudson, 1968; Marshall and Kennedy, 1974).

\subsection{Sample Collection}

\section{Materials and Methods}

The materials used for this study were rubber latex, bitumen, coarse and fine aggregates. The rubber latex used was obtained from Ikot Essien in Ibiono Ibom Local Government Area of Akwa Ibom State in Nigeria while the bitumen used was collected from the Federal Ministry of Works in Rivers State, Nigeria. Commercial aggregates were, however, used. After sampling of the materials, laboratory tests - specific gravity, grading of bitumen and sieve analysis of the aggregates used for mix-proportioning by straight line method were carried out.

\subsection{Sample Preparation}

Samples were prepared using Marshal Design Procedures for asphalt concrete mixes as presented in Asphalt Institute (1981), National Asphalt Pavement Association (1982) and Roberts et al (1996). The procedures involved the preparation of a series of test specimens for a range of asphalt (bitumen) contents such that test data curves showed well defined optimum values. Tests were scheduled on the bases of 0.5 percent increments of asphalt content with at least 3 -asphalt contents above and below the optimum asphalt content. In order to provide adequate data, three replicate test specimens were prepared for each set of asphalt content used. During the preparation of the unmodified asphalt concrete samples, the aggregates were first heated for about 5 minutes before bitumen was added to allow for absorption into the aggregates. After which the mix was poured into a mould and compacted on both faces with 35 blows using a $6.5 \mathrm{~kg}$-rammer falling freely from a height of $450 \mathrm{~mm}$. Compacted specimens were subjected to density and voids analysis to determine optimum asphalt content.

On the other hand the rubberized asphalt concrete samples were prepared under similar conditions as afore however, with additions of rubber latex at optimum asphalt content at varying amounts $0.5-3 \%$. Results obtained were then subjected to tensile strength tests using split cylinder and double punch testing techniques.

\subsection{Indirect Tensile Test using Split Cylinder}

The tensile characteristics of bituminous mixtures were evaluated by loading the Marshall specimen along a diametric plane with a compressive load at a constant rate acting parallel to and along the vertical diametrical plane of the specimen through two opposite loading strips. This loading configuration developed a relatively uniform tensile stress perpendicular to the direction of the applied load and along the vertical diametrical plane, ultimately causing the specimen being tested to fail by splitting along the vertical diameter.

A $13 \mathrm{~mm}\left(1 / 2^{\prime \prime}\right)$ wide strip loading was used for $102 \mathrm{~mm}$ diameter and $64 \mathrm{~mm}$ thick specimen to provide a uniform loading with which produced a nearly uniform stress distribution. The static indirect tensile 
strength of each specimen was determined using the procedure outlined in ASTM D 6931 were a loading rate of $51 \mathrm{~mm} /$ minute was adopted causing Tensile failure to occur in the sample rather than the compressive failure. Plywood strips were used so that the load is applied uniformly along the length of the cylinder. The compressive load indirectly created tensile load in the horizontal direction of the sample and the peak load at failure of specimen was recorded and was divided by appropriate geometrical factors to obtain the split tensile strength. The theoretical basis for computing the tensile strength of a split cylinder test has been derived from the theory of linear elasticity (Timoshenko, 1934: pp.104-108) for a solid disc as shown below using equation 1:

$$
S_{T}=\frac{2 P}{\pi T D}
$$

The theoretical basis for computing the tensile strength of a split cylinder test has been derived from the theory of linear elasticity (Timoshenko, 1934: pp.104-108).

Where;

$\mathrm{S}_{\mathrm{T}}=$ Tensile strength from split cylinder $-\mathrm{N} / \mathrm{mm}^{2}$

$\mathrm{P}=$ Maximum load at failure, $\mathrm{N}$

$t=$ specimen height immediately before test, $\mathrm{mm}$

$D=$ specimen diameter, $\mathrm{mm}$

The procedure was repeated for rubber latex modified bituminous concretes at varying amounts between 0.5 3.0 percent rubber latex content and peak loads measured at failure to ascertain the effect of rubber latex additions on the indirect tensile strengths of the mixtures.

\subsection{Double Punch Test}

The test was performed by loading concentrically an asphalt concrete cylinder of $64 \mathrm{~mm}$ height and $102 \mathrm{~mm}$ diameter top and bottom using two cylindrical steel punches of $25 \mathrm{~mm}$ diameter at a rate of $25 \mathrm{~mm} /$ minute until failure occurred. The applied load generated an almost uniform tensile stress across the vertical planes containing the load causing the specimen to split across the planes similar to that of the split cylinder test. The tensile strength was computed by adopting the equation developed by (Chen, 1969) as follows:

$$
f_{t}=\frac{Q}{\pi\left(1.2 b H-a^{2}\right)}
$$

Where;

$f_{t}=$ Tensile Strength from double punch test

$\mathrm{Q}=$ maximum load at failure

$\mathrm{a}=$ radius of punch $=12.5 \mathrm{~mm}$

$\mathrm{b}=$ radius of specimen $=51 \mathrm{~mm}$

$\mathrm{H}=$ height of specimen $=64 \mathrm{~mm}$

III. Results (Tables 1-4 \& Figure 1)

The results from the laboratory and analysis of the results are presented in the tables and figure below;

Table 1: Laboratory test Results of Materials

\begin{tabular}{|l|l|l|l|l|}
\hline Material & Rubber & asphalt & Sand & Gravel \\
\hline Specific gravity & 0.90 & 1.36 & 2.66 & 2.90 \\
\hline Grade of binder material & - & $40 / 50$ & - & - \\
\hline Mix proportion (\%) & - & - & 42 & 58 \\
Viscosity of binder (poise) & - & $0.45^{*}\left(10^{-6}\right)$ & - & - \\
Softening point & - & & - & - \\
Penetration value & - & $48^{\circ} \mathrm{C}$ & - & - \\
& & $44 \mathrm{~mm}$ & & \\
\hline
\end{tabular}

Table 2: Schedule of Aggregates used for Mix Proportion

\begin{tabular}{|l|l|l|l|l|}
\hline $\begin{array}{l}\text { Sieve size } \\
(\mathbf{m m})\end{array}$ & $\begin{array}{l}\text { Specification } \\
\text { limit }\end{array}$ & $\begin{array}{l}\text { Aggregate A } \\
\text { (Sand) }\end{array}$ & $\begin{array}{l}\text { Aggregate B } \\
\text { (Gravel) }\end{array}$ & $\begin{array}{l}\text { Mix proportion } \\
\mathbf{( 0 . 4 2 A + 0 . 5 8 B})\end{array}$ \\
\hline 19.0 & 100 & 100 & 100 & 100 \\
\hline 12.5 & $86-100$ & 100 & 97 & 98 \\
\hline 9.5 & $70-90$ & 100 & 62 & 78 \\
\hline 6.3 & $45-70$ & 100 & 26 & 57 \\
\hline
\end{tabular}


Laboratory Investigation of The Contributions of Rubber Latex to Tensile Strength of Hot Mix....

\begin{tabular}{|l|l|l|l|l|}
\hline 4.75 & $40-60$ & 99 & 10 & 47 \\
\hline 2.36 & $30-52$ & 96 & 0 & 40 \\
\hline 1.18 & $22-40$ & 90 & 0 & 38 \\
\hline 0.6 & $16-30$ & 73 & 0 & 31 \\
\hline 0.3 & $9-19$ & 23 & 0 & 10 \\
\hline 0.15 & $3-7$ & 3 & 0 & 1.26 \\
\hline 0.075 & 0 & 0 & 0 & 0 \\
\hline
\end{tabular}

Table 3: Tensile Strength from Split Cylinder Test for Pure HMA ( $0 \%$ Rubber) and Rubberized Asphalt Concrete (0.5-3\% Rubber)

\begin{tabular}{|l|l|l|l|l|}
\hline $\begin{array}{l}\text { Rubber Latex Content } \\
(\%)\end{array}$ & $\begin{array}{l}\text { Peak Load at Failure } \\
(\mathbf{N})\end{array}$ & $\begin{array}{l}\mathbf{T} \\
(\mathbf{m m})\end{array}$ & $\begin{array}{l}\mathbf{D} \\
(\mathbf{m m})\end{array}$ & $\boldsymbol{S}_{\boldsymbol{T}}\left(\mathbf{N} / \mathbf{m m}^{\mathbf{2}}\right)$ \\
\hline 0.0 & 1520 & 64 & 102 & 0.148213 \\
\hline 0.5 & 2326 & 64 & 102 & 0.226805 \\
\hline 1.0 & 2941 & 64 & 102 & 0.286773 \\
\hline 1.5 & 3290 & 64 & 102 & 0.320804 \\
\hline 2.0 & 1551 & 64 & 102 & 0.151236 \\
\hline 2.5 & 1451 & 64 & 102 & 0.141485 \\
\hline 3.0 & 321 & 64 & 102 & 0.0313 \\
\hline
\end{tabular}

Table 4: Tensile Strength from Double Punch Test for Pure HMA (0\% Rubber) and Rubberized Asphalt

\begin{tabular}{|l|l|l|l|l|l|}
\hline $\begin{array}{l}\text { Rubber Latex } \\
\begin{array}{l}\text { Content } \\
(\%)\end{array}\end{array}$ & $\begin{array}{l}\text { Peak Load at } \\
\text { Failure } \\
(\mathbf{N})\end{array}$ & $\begin{array}{l}\text { Radius of } \\
\text { punch a } \\
(\mathbf{m m})\end{array}$ & $\begin{array}{l}\text { Radius of specimen } \\
\mathbf{b} \\
(\mathbf{m m})\end{array}$ & $\begin{array}{l}\text { Height } \\
\text { specimen H } \\
(\mathbf{m m})\end{array}$ & $f_{t}$ \\
\hline 0.0 & 1520 & 12.5 & 51 & 64 & 0.128642965 \\
\hline 0.5 & 2326 & 12.5 & 51 & 64 & 0.196857589 \\
\hline 1.0 & 2941 & 12.5 & 51 & 64 & 0.24890721 \\
\hline 1.5 & 3290 & 12.5 & 51 & 64 & 0.278444311 \\
\hline 2.0 & 12.5 & 51 & 64 & 0.131266604 \\
\hline 2.5 & 1251 & 51 & 64 & 0.122803251 \\
\hline 3.0 & 1451 & 12.5 & 51 & 64 & 0.027167363 \\
\hline
\end{tabular}

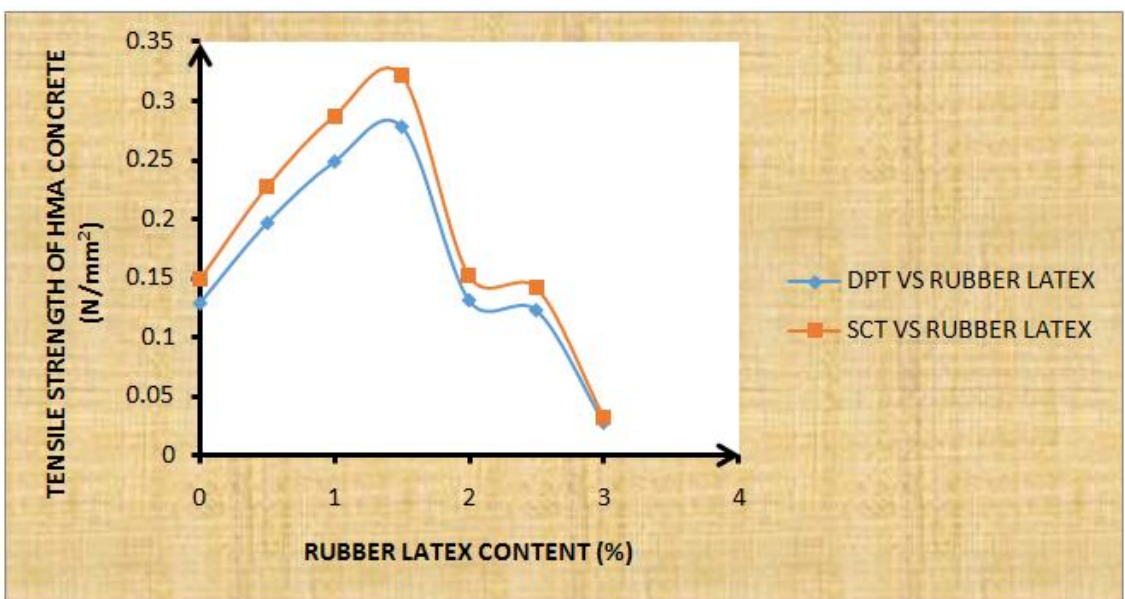

Figure 1: Tensile Strength of HMA Concrete Vs Rubber Latex

\section{Discussions}

The results of tensile strength variation from split cylinder and double punch tests with respect to varying rubber latex content is presented in Tables 3 and $4 \&$ Figure 1 above.

The results revealed that the indirect tensile strength of the asphalt concretes from split cylinder test increased with increasing rubber latex content from approximately $0.15 \mathrm{~N} / \mathrm{mm}^{2}$ at $0 \%$ rubber latex content to an optimum of approximately $0.32 \mathrm{~N} / \mathrm{mm}^{2}$ at $1.5 \%$ rubber latex content for a light traffic category (see Table 3 \& Figure 1). However, further increase in rubber latex content resulted in a decrease in tensile strength of the asphalt concrete from the split cylinder test.

In similar manner results from Table $4 \&$ Figure 1 revealed that the tensile strength of the asphalt concretes from double punch test increased with increasing rubber latex content from approximately 0.12 $\mathrm{N} / \mathrm{mm}^{2}$ at $0 \%$ rubber latex content to an optimum of approximately $0.28 \mathrm{~N} / \mathrm{mm}^{2}$ at $1.5 \%$ rubber latex content for a light traffic category. However, further increase in rubber latex content resulted in a decrease in tensile strength of the asphalt concrete from the double punch test. 


\section{Conclusions}

From the laboratory test results obtained including analysis made the following conclusions are drawn;

i. That rubber latex contributes significantly to tensile strength of hot mix asphalt for both split cylinder indirect tensile strength test and double punch indirect tensile strength test

ii. Tensile strength of the asphalt concretes from split cylinder test increased with increasing rubber latex content to a threshold value of $1.5 \%$ rubber latex content

iii. Tensile strength of the asphalt concretes from double punch test increased with increasing rubber latex content to threshold value of $1.5 \%$ rubber latex content

iv. Rubber latex addition caused a $113 \%$ increase in the tensile strength of the asphalt concretes from split cylinder test

v. Rubber latex addition caused a $133 \%$ increase in the tensile strength of the asphalt concretes from double punch test

vi. The results revealed that tensile strength from split test were higher than those from double punch test

\section{References}

[1] Anderson, D. A., Le Hir, Y. M., Marasteanu, M. O., Planche, J., and Martin, D. (2001) "Evaluation of Fatigue Criteria for Asphalt Binders." Transportation Research Record 1766, Transportation Research Board, Washington, D. C. 48-56.

[2] Asphalt Institute (1981) “Thickness Design-Asphalt Pavements for Highways and Streets", Manual Series No. 1.

[3] Bonnot, J. (1986) “Asphalt Aggregate Mixtures”, Transportation Research Record, 1096, Transportation Research Board, 42-51.

[4] Brown, E. R. and Foo, K. Y. (1989) 'Evaluation of Variability in Resilient Modulus Test Results' (ASTM D 41 23) National Centre for Asphalt Technology: Report No. 91-6.

[5] Chen, W.F.and Drucker, D. C., (1969) "Bearing Capacity of Concrete Blocks or Rock", Journal of the Engineering Mechanics, Division, American Society of Civil Engineers, Vol. 95, No. 4

[6] Chen, W. F. (1970) "Double Punch test for Tensile Strength of Concrete" ACI Journal, Proceedings V.67, No. 12, PP. 993-995

[7] Chen, W. F. (1975) "Limit Analysis and Soil Plasticity" Elsevier Scientific Publication Co., Amsterdam, p.638

[8] Epps, Jon A., and Carl L. Monismith, (1969) "Influence of Mixture Variables on Flexural Fatigue Properties of Asphalt Concrete," Proceedings, Association of Asphalt Paving Technologists, Vol. 38, pp 423-464.

[9] Garcia, G., and Thompson M. R., (2007) "HMA Dynamic Modulus Predictive Models: A Review", Report of the Findings of ICtR39: Validation of Extended Life HMA design Concepts, Research Report FHWA-ICT-07-005.

[10] Huang, B., Shu, X and Bass, J., (2008) "Investigation of Simple Performance Characteristics of Plant-Produced Asphalt Mixtures in Tennessee", Transportation Research Record: Journal of the Transportation Research Board No. 2057, TRB, National Research Council, Washington, D.C., 2008, pp 140-148.

[11] Igwe, E. A., Ayotamuno, M. J., Okparanma, R. N., Ogaji, S. O. T., and Probert, S. D., (2009) "Road Surface Properties affecting Rates of Energy Dissipation from Vehicles", Journal of Applied Energy, vol. 86, pp. 1692-1696, Elsevier Publishing.

[12] Igwe, E. A., (2015) "Effects of Air Voids Variation on Stiffness property of HMA Concrete Modified with Rubber Latex" International Journal of Emerging Trends in Engineering Research, Vol. 3, N0. 9. Available online @ http://www.warse.org/IJETER/static/pdf/file/ijeter02392015.pdf

[13] Kennedy, T. W., and Hudson, W. R. (1968) "Application of the Indirect Tensile Test to Stabilized Materials," Highway Research Record No. 235, Highway Research Board, pp 36-48.

[14] Malhotra, V. M. (1967) "Problems Associated with Determining the Tensile Strength on Concrete", Mines Branch Report, Department of Energy Mines and Resources, Ottawa, Canada, Vol. 10, No. A-6, Paper No. AIC-67-Civ-9, pp. 3 23,

[15] Mallick, R. B., and El-Korchi, T. (2013) "Pavement Engineering: Principles and Practice" second edition by Taylor \& Francis Group, CRC press, Boca Raton London New York.

[16] Marshall, B. P., and Kennedy, T. W. (1974) "Tensile and Elastic Characteristics of Pavement Materials," Research Report 183-1, Center for Highway Research, The University of Texas at Austin

[17] National Asphalt Pavement Association (1982) "Development of Marshall Procedures for Designing Asphalt Paving Mixtures", Information Series 84, National Asphalt Pavement Association Lanham, MD.

[18] Roberts, F. L. Kandhal, P. S., Brown, E. R.; Lee, D. Y. and Kennedy, T. W., (1996) "Hot Mix Asphalt Materials, Mixture Design, and Construction" National Asphalt Pavement Association Education Foundation Lanham, MD.

[19] Robins, M. M. (2009) "An investigation into dynamic complex modulus of Hot Mix Asphalt an it's contributing factor" Thesis presented to the Department of Civil Engineering, University of Toledo, USA, MSc Civil Engineering, Directed by David H. Timm.

[20] Romanoschi, S.A., Dumitru, N.I., and Dumitru, O. (2006) "Resilent Modulus and the Fatigue Properties of Kansas Hot Mix Asphalt Mixes"”, Final Report, No. K-TRAN: KSU-02-06, Kansas State University, Manhattan, Kansas.

[21] Said, S. F. (1998) "Validation of indirect tensile test for fatigue testing of bituminous mixes." Proj. 60209, Swedish National Road and Transport Research Institute, Linkoping, Sweden.

[22] Timoshonko, S. (1934) “Theory of Elasticity”, McGraw-Hill Book Company, New York, pp. 104-108. 